cultured fibroblasts: differentiation of Niemann-Pick disease Types A and B. Biochem Biophys Res Commun 105:14

3. Besley GTN 1976 The effect of Triton X-100 on the isoelectric focussing profile of fibroblast sphingomyelinase. FEBS Lett 72:101

4. Besley GTN 1978 Diagnosis of Niemann-Pick disease using a simple and sensitive fluorimetric assay of sphingomyelinase activity. Clin Chim Acta 90:269

5. Bradford M 1976 A rapid and sensitive method for the quantitation of microgram quantities of protein utilizing the principle of protein-dye binding. Anal Biochem 72:248

6. Brady RO 1978 In: Stanbury JD, Wyngaarden JB, Grederickson DS (eds) The Metabolic Basis for Inherited Disease, McGraw-Hill, New York, 4th ed, pp $718-730$

7. Christomanou H 1980 Niemann-Pick disease, Type C. Evidence for the deficiency of an activating factor stimulating sphingomyelin and glucocerebroside degradation. Z Physiol Chem 361:1489

8. Ellis DH, Jaunzems AE, Poulos A, Carey WF 1982 Ultrastructural studies on cultured fibroblasts from patients with lipid storage disorders. Proceedings of Human Genetics Society of Australia, Adelaide (Pathology 15:103)

9. Ginns EJ, Brady RO, Pirruccello S, Moore C, Sorrell S, Furbish FS, Murray GJ, Tager J, Barranger JA 1982 Mutations of glucocerebrosidase: discrimination of neurologic and non-neurologic phenotypes of Gaucher Disease. Proc Natl Acad Sci USA 79:5607

10. Ham RG, McKeeham WL 1978 Development of improved media and culture conditions for clonal growth of normal diploid cells. In Vitro 14:11

11. Huterer S, Wherrett JR, Poulos A, Callahan JW 1983 Deficiency of phospholipase $C$ acting on phosphatidyl glycerol in Niemann-Pick disease. Neurology 33:67

12. Jones CS, Shankaran P, Davidson DJ, Poulos A, Callahan JW 1983 Studies on the structure of sphingomyelinase: amino acid composition on isoelectric focussing. Biochem J 209:291

13. Maziere JC, Maziere C, Mora L, Routier JD, Polonovski J 1982 In situ degradation of sphingomyelin by cultured normal fibroblasts and fibroblasts from patients with Niemann-Pick disease Type A and C. Biochem Biophys Res Commun 108:1101

14. Peters SP, Coyle P, Coffee CJ, Glew RH, Kuhlenschmidt MS, Rosenfeld L, Lee YC 1977 Purification and properties of a heat-stable glucocerebrosidase activating factor from control and Gaucher spleen. J Biol Chem 252:563

15. Poulos A, Hudson N, Ranieri E 1983 Sphingomyelinase in cultured skin fibroblasts from normal and Niemann-Pick Type C patients. Clin Genet $24: 225$

16. Poulos A, Beckman K, Ellis DH, Pollard AC 1982 Hepatic storage of bis(monoacylglycerol) phosphate without concomitant storage of sphingomyelin in a 72 -year-old patient with partial deficiency of sphingomyelinase. Clin Genet 22:234

17. Poulos A, Beckman K 1980 The bile salt activation of leukocyte sphingolipid hydrolase activity and the modifying effects of Triton X-100. Clin Chim Acta 107:27

18. Poulos A, Shankaran P, Jones CS, Callahan JW 1984 Enzymatic hydrolysis of sphingomyelin liposomes by normal and Niemann-Pick tissues. Biochim Biophys Acta, in press

19. Poulos A, Lowden JA, Callahan JW 1982 Sphingomyelin storage disease: a new classification. Proceedings of the Human Genetics Society of Australia, Adelaide (Pathology 15:104)

20. Poulos A, Ranieri E, Shankaran P, Callahan JW 1984 Studies on the activation of the enzymatic hydrolysis of sphingomyelin liposomes. Biochim Biophys Acta 793:141

21. Vanier MT, Revol A, Fichet M 1980 Sphingomyelinase activities of various human tissues in control subjects and in Niemann-Pick disease--development and evaluation of a microprocedure. Clin Chim Acta 106:257

\title{
Treatment of Experimental Group B Streptococcal Infection with Hybridoma Antibody
}

\author{
ROBERT D. CHRISTENSEN, GERALD ROTHSTEIN, HARRY R. HILL, AND SETH H. PINCUS \\ Departments of Pediatrics, Internal Medicine, and Pathology, University of Utah School of Medicine and the \\ Primary Children's Medical Center, Salt Lake City, Utah, 84132
}

\begin{abstract}
Previous studies have shown a reduction in mortality rate from $90 \%$ to zero when neonatal rats, inoculated with group B streptococci (GBS) were injected with type-specific IgM antibody. However, in those studies, the antibody was administered simultaneously with the bacteria and at the same site, unlike the situation which would exist if antibody was used clinically to treat established infection. In the present experiments, we administered antibody intraperitoneally at various intervals following intrathoracic inoculation of GBS. When antibody was administered immediately after, or up to 2 h following bacterial inoculation, all animals survived. When antibody administration was delayed for 4,5 , or $6 \mathrm{~h}$, survival rates of 92,60 , and $29 \%$ were observed. When antibody administration was delayed for more than $6 \mathrm{~h}$, no survival occurred. Failure of antibody to protect animals from death
\end{abstract}

Received November 16. 1983; accepted March 19, 1984.

This work was supported by United States Public Health Service Grants HD14419, Al-13150, and AI-19094 and by two grants from the Thrashner Research Fund.

Requests for reprints may be addressed to Dr. Robert D. Christensen, Division of Hematology, University of Utah School of Medicine, 50 North Medical Drive, Salt Lake City, UT 84132 coincided temporally with profound depletion of the neutrophil storage pool. In other experiments, depletion of the neutrophil storage pool was produced by a separate, noninfectious mechanism (subcutaneous implantation of sterile polyvinyl sponge discs) after which animals were inoculated with GBS. Antibody did not provide protection from death in animals with neutrophil storage pool depletion. (Pediatr Res 18:1093-1096, 1984)

\section{Abbreviations}

GBS, group B streptococci PBS, phosphate-buffered saline

Current treatment methods fail to produce survival in as many as $25-30 \%$ of newborn infants with "early onset" bacterial sepsis (23). Diminished host resistance, due to incomplete development of the neutrophil system $(3,4,17,26)$ and in many infants, also due to diminished opsonizing capacity $(1,16)$ certainly contributes to their refractoriness to treatment. Because of the neonate's 
diminished host resistance, investigators have predicted that new adjunctive treatment modalities, directed at supplementing host defense, must be developed if further diminution in the mortality rate from sepsis neonatorum is to be made (18). One such potential modality is the administration of antibody. We have previously shown that when type-specific IgM antibody, prepared from hybridoma cell lines, was administered to neonatal animals together with bacteria, the mortality rate decreased from $90 \%$ to zero (5). In addition, our previous work demonstrated an important interaction between antibody and the neutrophil system: antibody facilitates rapid release of neutrophils from storage and enhances the efficiency of neutrophil migration toward the site of infection (5). Therefore, antibody may require an intact neutrophil supply for its protective action. In the present report, we demonstrate that this antibody did protect neonates who had established GBS infection; however, protection did not occur when the antibody was administered after the neutrophil storage pool had been depleted.

\section{MATERIALS AND METHODS}

Preparation of bacteria. Type III group B streptococci, identified by the precipitin method of Lancefield (14), were isolated from the blood of a human neonate with severe early onset disease. This was the same strain of type III GBS used in several of our previous reports $(3,5,7)$. The organisms were grown to logarithmic phase at $37^{\circ} \mathrm{C}$ in Todd-Hewitt broth, then washed three times with PBS and aliquots were frozen at $-70^{\circ} \mathrm{C}$. Prior to inoculation into rats, the aliquots were thawed and grown to logarithmic phase in fresh Todd-Hewitt broth. Bacteria were then sedimented by centrifugation and the concentrated organisms were washed three times in PBS. The suspensions were diluted in PBS to an optical density of 0.9 at $620 \mathrm{~nm}$ (Spectronic 20, Bausch and Lomb, Inc., Rochester, NY) producing a final concentration of $1 \times 10^{9}$ colony-forming units $/ \mathrm{ml}$.

Hybridoma antibody preparation. The details of production and characterization of monoclonal antibodies have been described elsewhere (19). In brief, BALB/c mice were multiply immunized with live type III GBS. Animals were sacrificed and their spleens were removed. Spleen cells were then fused with nonsecreting SP 2/0 cells using polyethylene glycol. Following incubation in selective media containing hypoxanthine, aminopterin, and thymidine, antibody-secreting cells were detected using an enzyme-linked immunoassay (20). Cells were cloned by limiting dilution. Nine cloned cell lines were produced: three reacted with all GBS and six with only type III GBS; all were IgM as determined by reaction with specific anti-IgM heavy chain antibody (Cappell Laboratories, Cochraneville, PA). Ascites fluid was collected from animals injected intraperitoneally with hybridoma cells. Antibody preparations for these experiments were made by dialyzing ascites fluid against distilled water and resuspending the precipitate in PBS.

Animal inoculation. Sprague-Dawley albino rats from Simonson Laboratories (Gilroy, CA) were inoculated while in the first $24 \mathrm{~h}$ of life. After washing the right lateral chest wall with $70 \%$ ethyl alcohol, the right lung was transthoracically injected with $1 \mu \mathrm{l} / \mathrm{g}$ body wt of a suspension of type III group B streptococci containing $10^{9}$ organisms $/ \mathrm{ml}$ using a Hamilton microliter syringe (Hamilton Co., Whittier, CA). The injection site was then held with forceps for several seconds to prevent leakage of the bacterial inoculum. If any leakage of bacterial suspension from the injection site was detected, the animal was discarded.

Either at the time of GBS inoculation or at various intervals thereafter, animals received an intraperitoneal injection of antibody. One microliter, containing $9.0 \mu \mathrm{g}$ protein, was administered using a Hamilton microliter syringe. In other experiments $10 \mu \mathrm{l}(90.0 \mu \mathrm{g}$ of protein) was administered. As with the GBS inoculation, following antibody administration the injection site was firmly held with forceps for several seconds to prevent leakage.

Sponge implantation. Polyvinyl sponge discs (Unipont Indus- tries, Inc., High Point, NC) were boiled in distilled water for 30$45 \mathrm{~min}$. Three $\mathrm{mg}$ of sponge/g body wt were then saturated with sterile Hanks' balanced salt solution and sterilely placed into surgically created subcutaneous pockets on the dorsum of newborn rats. The entrance of the subcutaneous pocket was then closed with $5 / 0$ silk suture and sealed with Flexible Collodion, U.S.P. (Robinson Laboratories, Inc., San Francisco, CA).

Quantification of storage neutrophils. The total neutrophil storage pool was calculated using methods we have described previously (6), by determining the number of polymorphonuclear leukocytes, band neutrophils, and metamyelocytes within the liver, spleen, and skeletal bone marrow. The liver and spleen were passed through sieves for nucleated cell count and differential cell counting and marrow was flushed from both femurs. The relationship of the combined femoral marrow to the total skeletal marrow has been reported previously (11).

Significance testing. Chi square analysis was used to test the null hypothesis.

\section{RESULTS}

Mortality studies. During the first $24 \mathrm{~h}$ of life, 169 rats received a transthoracic inoculation of $10^{6}$ type III group B streptococci/ $\mathrm{g}$ body wt. In addition, all animals received an intraperitoneal injection of $1 \mu \mathrm{l}$ of IgM anti-type III group B streptococcal antibody. In 50 animals, the antibody was administered immediately following GBS inoculation and in the others, antibody administration was delayed for 1-9 h. As is shown in Table 1, all 50 animals which received antibody at the time of GBS inoculation survived, as did all animals which received antibody within $2 \mathrm{~h}$ following GBS inoculation. When antibody administration was delayed until $4 \mathrm{~h}$ after GBS, $92 \%$ of animals survived; when it was delayed for $5 \mathrm{~h}, 60 \%$ survived. Survival fell to $29 \%$ when the antibody was administered $6 \mathrm{~h}$ following GBS inoculation, and when antibody administration was delayed for $7 \mathrm{~h}$ or longer no animals survived.

Depletion of the neutrophil reserves following sponge implantation. In previous studies, we observed that $5-7 \mathrm{~h}$ following inoculation of $10^{6}$ type III group B streptococci/g body wt, newborn rats invariably develop profound neutropenia and depletion of the neutrophil reserves (5-7). In the present studies, we noted that 5-7 $\mathrm{h}$ after GBS inoculation, during the period of profound neutropenia and neutrophil reserve depletion, death could not be prevented by antibody administration. Because of this temporal relationship, we speculated that in order to provide protection from death, antibody required an intact neutrophil system, and that if the neutrophil supply was exhausted antibody administration would not prevent septic death. Therefore, in other studies, we first depleted the neutrophil supply of newborn rats by subcutaneous implantation of a sterile polyvinyl sponge (4). We then evaluated the ability of type-specific antibody to promote survival among rats whose neutrophil supply had been exhausted prior to GBS inoculation.

Figure 1 shows the size of the neutrophil storage pool in newborn rats at intervals following sterile polyvinyl sponge implantation. Two hours after the sponge had been implanted, no detectable diminution in storage neutrophils had occurred, but by $6 \mathrm{~h}$ the quantity of reserve neutrophils had been reduced to $16 \pm 8 \%$ (mean $\pm 2 \mathrm{SD}$ ) of the initial level, indicating that $84 \pm$ $8 \%$ of the neutrophil supply had been released. At 20,24 , and $48 \mathrm{~h}$ following sponge implantation, storage neutrophils remained at a similarly low level, but at 120 and $144 \mathrm{~h}$, increases were observed. In order to detect bacterial contamination of sponge implants, 10 animals were sacrificed $6 \mathrm{~h}$ after sponge implantation and sponges were removed for bacterial culture. Bacterial growth was not detected in any of the sponges.

Mortality in neutrophil-depleted animals. When 120 control uninfected animals were subjected to no manipulation (aside from counting), 116 were alive $48 \mathrm{~h}$ later. Sponge implantation alone did not cause significant mortality as evidenced by the survival of 28 of 30 animals $48 \mathrm{~h}$ after being subjected to sponge 
Table 1. Survival* of newborn rats transthoracically inoculated with group B streptococci followed by intraperitoneal hybridoma antibody

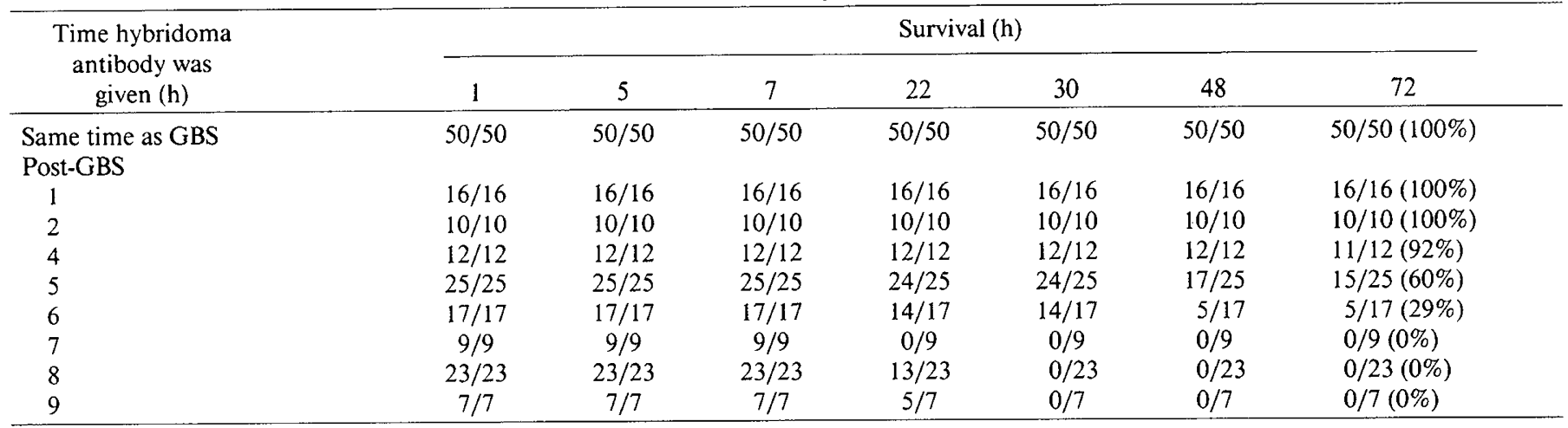

* Number surviving/number inoculated.

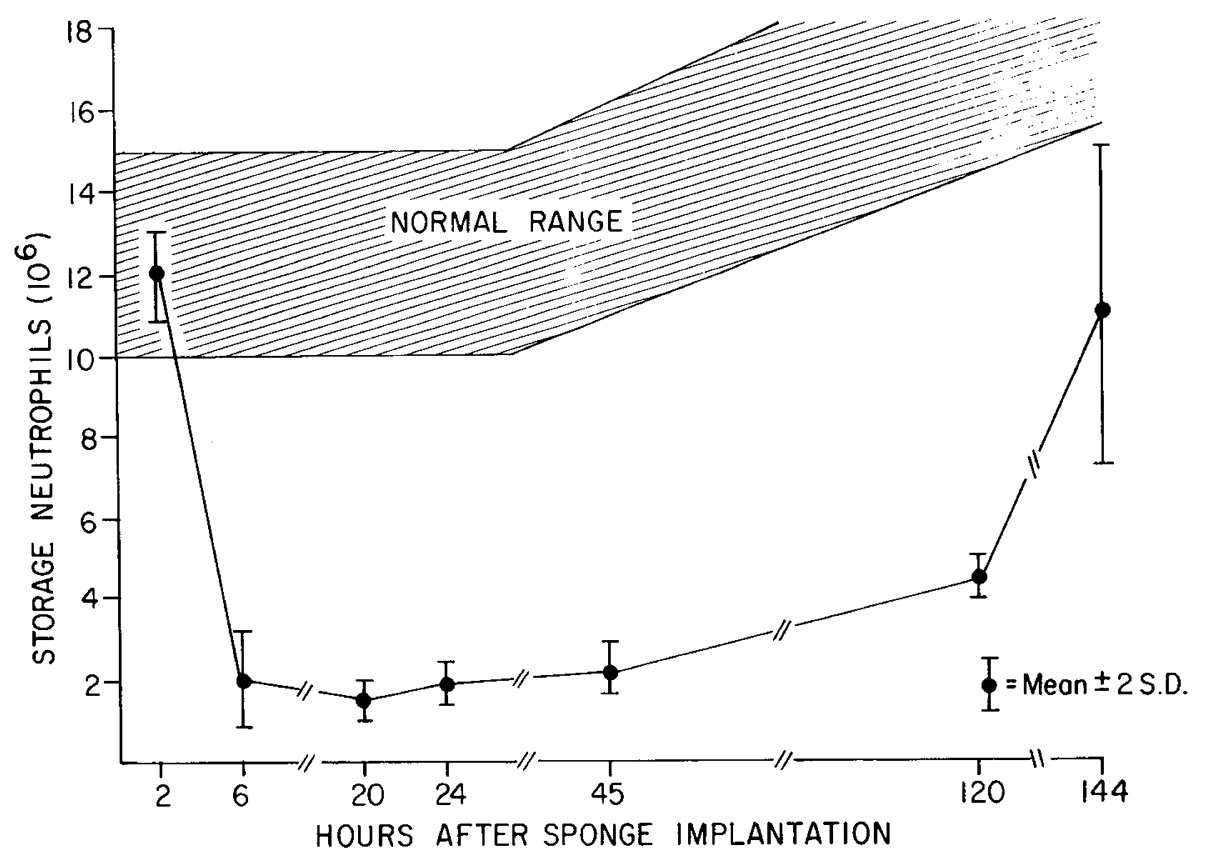

Fig. 1. Storage neutrophils (all polymorphonuclear + band neutrophils + metamyelocytes within the liver, spleen, and skeletal bone marrow) in groups of 10 or more newborn rats at various intervals following the subcutaneous placement of a sterile polyvinyl sponge disc. The range of values for storage neutrophils in neonatal rats without subcutaneous sponges is given as the shaded area. A marked diminution in storage neutrophils was observed $6 \mathrm{~h}$ following sponge placement $(p<0.001)$.

implantation. As is shown in Table 2 , inoculation of $10^{6}$ type III group B streptococci/g body wt resulted in $100 \%$ mortality among 19 normal newborn rats, and all deaths occurred within $40 \mathrm{~h}$ of GBS inoculation. When animals with sponge-induced depletion of the neutrophil reserves were inoculated with GBS, $100 \%$ mortality was also observed; however, death occurred earlier, with 13 of 17 deaths within the first $20 \mathrm{~h}$ following GBS inoculation $(p<0.001)$. The effect of hybridoma antibody on survival in infected normal and neutrophil-depleted rats is also shown in Table 2 . When antibody was given simultaneously with bacteria, no normal rats died, but death occurred in 10 of 11 who had pre-existing neutrophil depletion. The antibody may have delayed death, however, because as seen above, when antibody was not given to animals with neutrophil reserve depletion death generally occurred within $24 \mathrm{~h}$ of GBS inoculation; yet when antibody was provided, no deaths occurred within the first $24 \mathrm{~h}$. Similarly, when antibody was administered $4 \mathrm{~h}$ after GBS inoculation, 12 of 12 normal neonatal rats survived, but no survival occurred among 12 neutrophil-depleted neonates. Again, a partial effect can be inferred from the fact that no deaths occurred within the first $24 \mathrm{~h}$ following inoculation. When antibody was administered $6 \mathrm{~h}$ after GBS inoculation, 5 of 17 normal neonates, but none of 17 neutrophil reserve-depleted neonates, survived $(p<0.01)$. Furthermore, deaths occurred earlier in the neutrophil-depleted neonates: $20 \mathrm{~h}$ after GBS inoculation no deaths had yet occurred in the normal animals, but 12 of 17 neutrophil-depleted animals had died $(p<0.001)$.

In other experiments, the effect of increasing the dose of antibody in neutrophil-depleted, GBS-infected animals was tested. Fourteen neutrophil-depleted animals were transthoracically inoculated with $10^{6} \mathrm{GBS} / \mathrm{g}$ body wt and immediately thereafter received an intraperitoneal injection of either 9.0 or 90.0 $\mu \mathrm{g}$ antibody. Twenty others, also neutrophil depleted, received $10^{6} \mathrm{GBS} / \mathrm{g}$ and after $4 \mathrm{~h}$, either 9.0 or $90.0 \mu \mathrm{g}$ antibody were given. In both experiments, there was no improvement in survival among animals who received the higher dose of antibody.

\section{DISCUSSION}

Because of the frequently disappointing result when neonatal sepsis is treated with antibiotics alone, investigators have suggested that adjunctive measures, such as exchange transfusion $(24,25)$, granulocyte transfusion $(2,8,9,15)$, or antibody administration $(5,10,13,21,22)$ should be tested. While some 
Table 2. Survival* in newborn rats inoculated with group B streptococci with or without prior neutrophil depletion

\begin{tabular}{|c|c|c|c|c|c|}
\hline \multirow[b]{2}{*}{ Group } & \multicolumn{5}{|c|}{ Survival (h) } \\
\hline & 7 & 20 & 24 & 40 & 48 \\
\hline No manipulation & $120 / 120$ & $119 / 120$ & $116 / 120$ & $116 / 120$ & $116 / 120$ \\
\hline Sponge alone & $30 / 30$ & $30 / 30$ & $28 / 30$ & $28 / 30$ & $28 / 30$ \\
\hline GBS alone & $19 / 19$ & $15 / 19 \dagger$ & $15 / 19 \dagger$ & $0 / 19$ & $0 / 19$ \\
\hline $\begin{array}{l}\text { GBS after neutrophil } \\
\text { depletion }\end{array}$ & $17 / 17$ & $4 / 17 \dagger$ & $2 / 17 \dagger$ & $0 / 17$ & $0 / 17$ \\
\hline $\begin{array}{l}\text { GBS and antibody } \\
\text { (normal animal) }\end{array}$ & $50 / 50$ & $50 / 50$ & $50 / 50$ & $50 / 50 \dagger$ & $50 / 50 \dagger$ \\
\hline $\begin{array}{l}\text { GBS and antibody } \\
\text { (neutrophil-de- } \\
\text { pleted animal) }\end{array}$ & $11 / 11$ & $11 / 11$ & $11 / 11$ & $3 / 11 \dagger$ & $1 / 11 \dagger$ \\
\hline $\begin{array}{l}\text { Antibody } 4 \mathrm{~h} \text { after } \\
\text { GBS (normal ani- } \\
\text { mal) }\end{array}$ & $12 / 12$ & $12 / 12$ & $12 / 12$ & $12 / 12 \dagger$ & $12 / 12 \dagger$ \\
\hline $\begin{array}{l}\text { Antibody } 4 \mathrm{~h} \text { after } \\
\text { GBS (neutrophil- } \\
\text { depleted animal) }\end{array}$ & $12 / 12$ & $12 / 12$ & $12 / 12$ & $0 / 12 \dagger$ & $0 / 12 \dagger$ \\
\hline $\begin{array}{l}\text { Antibody } 6 \mathrm{~h} \text { after } \\
\text { GBS (normal ani- } \\
\text { mal) }\end{array}$ & $17 / 17$ & $17 / 17 \dagger$ & $14 / 17 \dagger$ & $8 / 17 \dagger$ & $5 / 17 \ddagger$ \\
\hline $\begin{array}{l}\text { Antibody } 6 \mathrm{~h} \text { after } \\
\text { GBS (neutrophil- } \\
\text { depleted animal) }\end{array}$ & $17 / 17$ & $5 / 17 \dagger$ & $2 / 17 \dagger$ & $0 / 17 \dagger$ & $0 / 17 \ddagger$ \\
\hline
\end{tabular}
* Number surviving/number inoculated.
$\dagger p<0.001$ between normal and neutrophil-depleted animals.
$\ddagger p<0.01$ between normal and neutrophil-depleted animals.

studies suggest that each of these approaches might have merit, it is currently unclear which, if any, of these measures should be employed in various clinical situations. In order to design appropriate clinical trials in which these new putative treatments are tested, the conditions which might favor their failure or success should first be understood and experiments which simulate clinical trials should be conducted using animal models. In order to better understand the mechanism of action of type-specific hybridoma antibody, several experiments have already been performed. Our previous work (5) as well as the studies of Harris et al. (13) suggest that IgM hybridoma antibody does not kill bacteria directly, but rather acts as a potent opsonin. In addition, we have demonstrated that the antibody facilitates prompt release of neutrophils from the neutrophil storage pool into the blood, and also improves the directionality of neutrophils which have been released from the marrow reserves (5). In addition, Hathorn et al. (12) showed a more rapid and complete bacterial killing in vitro when antibody was attached to neutrophils. These studies support the concept that the neutrophil system must be functional if IgM hybridoma antibody administration is to be of value. The present studies further support this hypothesis. First, when antibody was administered early in the course of illness, while the neutrophil reserves were still intact $(5,7)$, the mortality rate fell from $100 \%$ to zero. Second, if antibody was given to animals after their neutrophil reserves had become depleted (5$7 \mathrm{~h}$ following bacterial inoculation), the salutary effect of the antibody upon survival was no longer observed. Third, when the neutrophil reserves were depleted by a noninfectious stimulus, after which animals were inoculated with GBS, no protective effect from antibody was observed.

Caution must be used in the interpretation of these latter studies: although sponges do deplete the neutrophil reserves, it is possible that they also produce other unrecognized changes in host defense status and that factors other than neutrophil deple- tion are responsible for the lack of effect of antibody in spongebearing animals. Nonetheless, because of the experimental data and theoretic considerations presented here, we suggest that antibody administration may eventually have a therapeutic role in life-threatening bacterial infection. Furthermore, we suggest that when clinical trials with antibody preparations are employed, investigators make an effort to determine the status of the neutrophil reserve of antibody recipients so that a correlation can be sought between benefit from antibody administration and presence or absence of neutrophil reserves.

\section{REFERENCES}

1. Baker CJ, Kasper DL 1976 Correlation of maternal antibody deficiency with susceptibility to neonatal group B streptococcal infection. N Engl J Med 294:753

2. Cairo MS, Johnson S, Bennetts GA, Rucker R, Hicks D, Worchester C, Amile R. Kats J 1983 Prospective randomized trial of polymorphonuclear leukocyte transfusions for septic neonates. Pediatr Res 17:306 (abstr)

3. Christensen RD. Hill HR, Rothstein G 1983 Granulocytic stem cell (CFUc) proliferation in experimental group B streptococcal sepsis. Pediatr Res 17:278

4. Christensen RD, Rothstein G 1980 The efficiency of neutrophil migration in the neonate. Pediatr Res 14:1147

5. Christensen RD, Rothstein G, Hill HR, Pincus SH 1983 The effect of hybridoma antibody administration upon neutrophil kinetics during experimental type III group B streptococcal sepsis. Pediatr Res 17:795

6. Christensen RD, Shigeoka AO, Hill HR, Rothstein G 1980 Circulating and storage neutrophil changes in experimental type II group B streptococcal sepsis. Pediatr Res 14:806

7. Christensen RD, Macfarlane JL, Taylor NL, Hill HR, Rothstein G 1982 Blood and marrow neutrophils during experimental group $B$ streptococcal infection: quantification of the stem cell, proliferative, storage and circulating pools. Pediatr Res 16:549

8. Christensen RD, Rothstein G, Anstall HB, Bybee B 1982 Granulocyte transfusions in neonates with bacterial infection, neutropenia and depletion of mature marrow neutrophils. Pediatrics 70:1

9. Christensen RD, Bradley PP, Priebat DA, Anstall HB, Rothstein G 1982 Granulocyte transfusion in septic canine neonates. Pediatr Res 16:57

10. Egan ML. Pritchard DG. Dillon HC Jr, Gray BM 1983 Protection of mice from experimental infection with type III group B streptococcus using monoclonal antibodies. J Exp Med 158:1006

11. Erdman SH. Christensen RD. Bradley PP, Rothstein G 1982 The supply and release of storage neutrophils: a developmental study. Biol Neonate 41:132

12. Hathorn JW, DeFranco AC, Hiemenez JW, Cotton DJ, Schaufele R, Sadoff J, Pizzo PA 1983 Enhanced bacterial killing by "armed neutrophils". Pediatr Res 17: 272 (abstr)

13. Harris MC. Douglas SP, Kolski GB, Polin RA 1982 Functional properties of anti-group B streptococcal antibodies. Clin Immunol Immunopathol 24:342

14. Lancefield RC 1938 A microprecipitin technique for classifying hemolytic streptococci and improved methods for producing antisera. Proc Soc Exp Biol Med 38:473

15. Laurenti F. Ferro R. Isacchi G, Panero A, Salvigno GP, Malagino R, Palmero $D$, Bucci G 1981 Polymorphonuclear leukocyte transfusion for the treatment of sepsis in the newborn infant. J Pediatr 98:188

16. McCracken GH Jr, Eichenwald HF 1971 Leukocyte function and the development of opsonic and complement activity in the neonate. Am J Dis Child 121:120

17. Miller ME 1971 Chemotactic function in the human neonate: Humoral and cellular aspects. Pediatr. Res. 5:487

18. Miller ME 1978 Host Defenses in the Human Neonate. Grune and Stratton, Inc., New York, pp 1-3

19. Pincus SH. Ewing LP. Stocks CJ 1982 Anti-(T,G)-A-L hybridomas. Fine specificity and idiotypic characterization. Mol Immunol 19:1551

20. Rote NS, Taylor NL, Shigeoka AO, Scott JR, Hill HR 1980 Enzyme linked immunosorbent assay for group B streptococcal antibodies. Infect Immun 27:118

21. Santos JI, Shigeoka AO, Rote NS, Hill HR 1981 Protective efficacy of a modified immune serum globulin in experimental group B streptococcal infection. J Pediatr 99:873

22. Shigeoka AO, Pincus SH, Rote NS, Hill HR 1982 Hybridoma type-specific IgM antibody offers enhanced protection against systemic or respiratory group B streptococcal experimental infection. Pediatr Res 16:231 (abstr)

23. Siegle JD, McCracken GH Jr 1981 Sepsis neonatorum. N Engl J Med 304:642

24. Tollner U, Pohlandt F, Heinze F, Henrichs L 1977. Treatment of septicemia in the newborn infant: choice of initial antimicrobial drugs and the role of exchange transfusion. Acta Paediat Scand 66:605

25. Vain NE, Mazulmain JR, Swarner OW, Cha CC 1980 Role of exchange transfusion in the treatment of severe septicemia. Pediatrics 66:693

26. Wright WC Jr, Ank BJ. Herbert J, Stiehm ER 1979 Decreased bactericidal activity of leukocytes of stressed newborn infants. Pediatrics 56:579 